\title{
Campylobacter cuniculorum sp. nov., from rabbits
}

\author{
Correspondence \\ Mirko Rossi \\ mirko.rossi@helsinki.fi
}

\author{
Renato Giulio Zanoni, ${ }^{1}$ Lies Debruyne, ${ }^{2}$ Mirko Rossi, ${ }^{1} \dagger$ Joana Revez ${ }^{1}$ \\ and Peter Vandamme ${ }^{2}$
}
${ }^{1}$ Department of Veterinary Public Health and Animal Pathology, Alma Mater Studiorum, University of Bologna, Via Tolara di Sopra 50, 40064 Ozzano Emilia, Bologna, Italy
${ }^{2}$ Department of Biochemistry, Physiology and Microbiology, Faculty of Sciences, Ghent University, K. L. Ledeganckstraat 35, B-9000 Gent, Belgium

\begin{abstract}
Eight strains of an unknown thermotolerant Campylobacter species were isolated from the caecal contents of rabbits (Oryctolagus cuniculus). All strains were initially identified as belonging to the genus Campylobacter by means of genus-specific PCR, but none were identified using speciesspecific PCR for known thermophilic species. Cells were spiral shaped with bipolar unsheathed flagella, with no periplasmic fibres, and appeared coccoid after 10-12 days of incubation.

Phylogenetic analyses based on 16S rRNA gene, rpoB and groEL sequences revealed that all strains formed a robust clade that was very distinct from recognized Campylobacter species. 16S rRNA gene sequence pairwise comparisons of strain $150 \mathrm{~B}^{\top}$ with the type strains of other Campylobacter species revealed that the nearest phylogenetic neighbour was Campylobacter helveticus NCTC $12470^{\top}$, with $96.6 \%$ similarity. The uniqueness of these rabbit isolates was confirmed by whole-cell protein electrophoresis. Taken together, these data indicate that the strains belong to a novel Campylobacter species for which the name Campylobacter cuniculorum sp. nov. is proposed, with $150 B^{\top}$ (=LMG $24588^{\top}=$ CCUG $\left.56289^{\top}\right)$ as the type strain.
\end{abstract}

The genus Campylobacter was proposed by Sebald \& Véron (1963). In the following decades, this genus has expanded with the description of species originating from mammals and birds and now, after various reclassifications, includes 18 established species and six subspecies (Foster et al., 2004; Vandamme et al., 2005; Inglis et al., 2007). So far, the few reports on the isolation of campylobacters from rabbits include strains of Campylobacter jejuni (Prescott \& BruinMosch, 1981; Weber et al., 1982) and a Campylobacter-like organism (Reynaud et al., 1993) from healthy and diarrhoeic animals. In the present paper, we describe the results of a polyphasic taxonomic investigation of eight strains of a Campylobacter-like organism recovered from rabbits (Oryctolagus cuniculus) in Italy.

Eight Campylobacter-like unidentified isolates were recovered from the caecal contents of eight rabbits during routine

tPresent address: Department of Food and Environmental Hygiene, University of Helsinki, PO Box 66, Agnes Sjöbergin katu 2, Fl-00014 Helsinki, Finland.

The GenBank/EMBL/DDBJ accession numbers for the 16S rRNA, rpo $B$ and groE $L$ gene sequences of strains $150 B^{\top}, 117 / 07$ and 120/07 are DQ400345, EU636818 and EU636820 (16S rRNA gene), EU636830, EU636833 and EU636836 (rpoB) and EU636828, EU636824 and EU636827 (groEL), respectively.

Neighbour-joining dendrograms based on $r p o B$ and groEL partial gene sequences are available as supplementary material with the online version of this paper. bacteriological analysis. The isolates were obtained between 2005 and 2007 from animals reared in intensive and extensive farms in different regions, thereby representing a temporally, geographically and epidemiologically independent set of isolates. Isolations were made after 6-8 days of incubation at $37{ }^{\circ} \mathrm{C}$ in a microaerobic atmosphere with hydrogen, on nutrient sheep-blood agar [nutrient broth No. 2 (Oxoid) with $1.5 \%$ Bacto agar (Difco) and $5 \%$ sheep blood] plus cefoperazone, amphotericin B, teicoplanin selective supplement (CAT; Oxoid), on modified-charcoal cefoperazone deoxycholate agar (CM0739; Oxoid) and on nutrient sheep-blood agar using a filter method (Zanoni et al., 2007). The microaerobic atmosphere with hydrogen was obtained by the gas replacement method using an anaerobic gas mixture $\left(10 \% \mathrm{H}_{2}, 10 \% \mathrm{CO}_{2}, 80 \%\right.$ $\mathrm{N}_{2}$ ) as described by Bolton et al. (1992).

After 6 days of incubation on nutrient sheep-blood agar, colonies were $1-2 \mathrm{~mm}$ in diameter, grey-green, flat with rough margins and slightly mucoid-looking; sometimes the colonies were $\alpha$-haemolytic and exhibited a tailing effect along the streak line. Cells were Gram-negative, pleomorphic, typically sigmoid to allantoid in shape, $2.6 \pm 0.7 \mu \mathrm{m}$ (mean $\pm \mathrm{SD})$ in length and $0.3 \pm 0.1 \mu \mathrm{m}$ in width when observed after Gram-staining. Cells appeared coccoid after 10-12 days of incubation.

Bacterial DNA was extracted by using a ChargeSwitch gDNA Mini bacteria kit (Invitrogen). The strains were 
identified as Campylobacter using the genus-specific PCR described by Linton et al. (1996), but were not identified at the species level using species-specific PCR tests for Campylobacter coli and C. jejuni (Denis et al., 1999), for C. upsaliensis and C. helveticus (Lawson et al., 1997) or for C. lari (Linton et al., 1996).

In order to establish the taxonomic position of the rabbit isolates, a phylogenetic analysis based on the sequences of the 16S rRNA gene was carried out. The nearly complete $16 \mathrm{~S}$ rRNA gene was amplified using universal primers $\mathrm{p} 27 \mathrm{f}$ $\left(5^{\prime}\right.$-AGAGTTTGATCCTGGCTCAG-3') and p1492r (5'TACGGCTACCTTGTTACGACT-3') and the PCR-amplified template was sequenced by primer walking (Primm SRL). Sequences were assembled with VECTOR NTI software (Invitrogen) and then aligned in BioEdit (http:// www.mbio.ncsu.edu/BioEdit/bioedit.html) with CLUSTAL w using publicly available Campylobacter reference sequences. The alignment was adjusted visually, removing intervening sequence regions and unknown bases, and data were corrected for multiple base changes by the method of Jukes \& Cantor (1969). A phylogenetic tree was constructed in MEGA3 (http://www.megasoftware.net/) using the neighbour-joining method. Bootstrap analysis was performed with 1000 reassembled datasets.

A fragment of $1283 \mathrm{bp}$ of the 16S rRNA gene was sequenced from each strain and a search of the NCBI database using MEGABLAST (http://www.ncbi.nlm.nih.gov/ blast/) determined that the strains were most closely related to taxa within the genus Campylobacter, confirming the results from the genus-specific PCR. Pairwise comparisons of 16S rRNA gene sequences showed that the rabbit isolates were genetically highly related to each other, exhibiting
99.1-100 \% sequence similarity. Furthermore, the neighbour-joining dendrogram (Fig. 1) indicated that all eight strains formed a robust clade (100\% bootstrap support) that was clearly distinct from all other Campylobacter species. Pairwise sequence comparisons of strain $150 \mathrm{~B}^{\mathrm{T}}$ with the type strains of the most closely related species revealed similarities of $96.6,96.5$ and $96.1 \%$ with $C$. helveticus NCTC $12470^{\mathrm{T}}$, C. jejuni NCTC $11351^{\mathrm{T}}$ and $C$. upsaliensis CCUG $14913^{\mathrm{T}}$, respectively.

In view of the low 16S rRNA gene sequence divergence between the unidentified strains and other Campylobacter species, the phylogenetic relationships were further examined by $r p o B$ (Korczak et al. 2006) and groEL (Kärenlampi et al., 2004) sequence analysis. Sequences were processed as described above. Phylogenetic trees based on partial nucleotide sequences of $r p o B$ and groEL from eight strains and reference Campylobacter strains are shown in Supplementary Fig. S1 (available in IJSEM Online). In both trees, all of the unidentified strains clustered together in a tight clade clearly separated from all other Campylobacter species ( $100 \%$ bootstrap support). The rpoB sequence similarity values within the clade of the rabbit strains were 97.9-100\%, while the similarity values towards the other Campylobacter species were 60.5-80.5\%. Likewise, groEL sequence similarity values among the rabbit strains were $97.7-100 \%$ and values between strain $150 \mathrm{~B}^{\mathrm{T}}$ and other Campylobacter species were below $86 \%$. Similarly to Korczak et al. (2006) and Kärenlampi et al. (2004), we observed good congruence between rpoB, groEL and $16 \mathrm{~S}$ rRNA gene sequence results, since each of the phylogenetic trees showed a similar topology. However, compared to the $16 \mathrm{~S}$ rRNA gene sequence analysis, the $r p o B$ and groEL sequence analysis showed lower interspecies similarity.

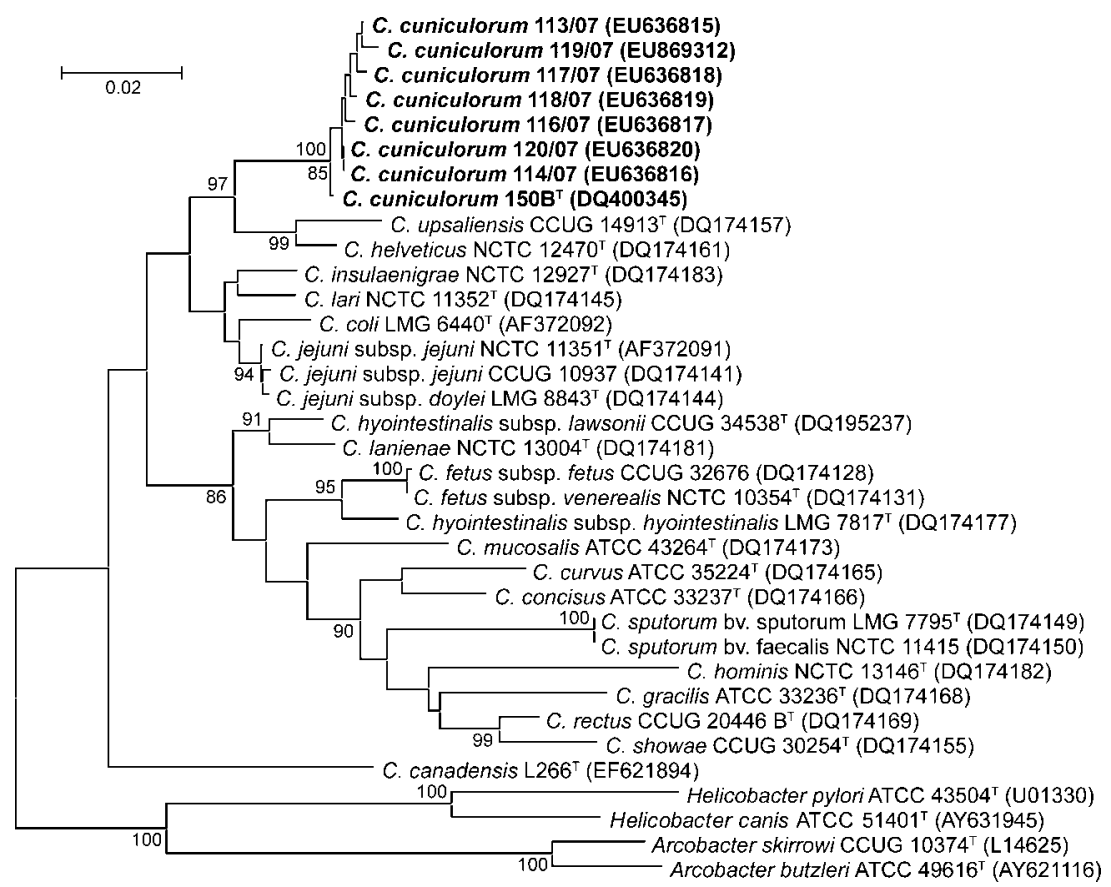

Fig. 1. Unrooted tree based on $16 \mathrm{~S}$ rRNA gene sequences showing the relationships of the eight strains of Campylobacter cuniculorum sp. nov. with related species. Numbers at nodes $(\geqslant 85 \%)$ indicate support for internal branches within the tree obtained by bootstrap analysis (percentages of 1000 bootstraps). Bar, 0.02 nucleotide substitutions per base. 
Although all sequence data demonstrated that the eight isolates represent a coherent taxon, whole-cell protein electrophoresis was used to examine further the relationships between the isolates. Whole-cell protein electrophoresis was performed after culturing strains on MuellerHinton agar supplemented with $5 \%$ horse blood at $37{ }^{\circ} \mathrm{C}$ for $48 \mathrm{~h}$ under microaerobic conditions with hydrogen. Protein extraction and SDS-PAGE were performed as described by Pot et al. (1994). Similarity between the normalized whole-cell protein patterns was determined by the Pearson product-moment correlation coefficient, after which clustering was performed by the unweighted pair group method with arithmetic averages (UPGMA), using GELCOMPAR version 4.2 (Applied Maths). As with many other Campylobacter species, a prominent protein band with variable position $(36.1-43.2 \mathrm{kDa})$ was present in the profiles of the rabbit isolates (Fig. 2) and, for numerical analysis, the region was excluded to increase species discrimination (Vandamme et al., 1991). Excluding this variable dense band region from the numerical analysis to enhance species-level discrimination resulted in a clear grouping of the rabbit isolates.

DNA-DNA hybridizations were subsequently performed between strains $150 \mathrm{~B}^{\mathrm{T}}$ and $116 / 07$. For this purpose, DNA was extracted from $0.25-0.5 \mathrm{~g}$ (wet weight) cells as described by Pitcher et al. (1989). DNA-DNA hybridizations were performed at $30{ }^{\circ} \mathrm{C}$ with photobiotin-labelled probes in microplate wells (Ezaki et al., 1989) using an HTS7000 Bio Assay Reader (PerkinElmer) for the fluorescence measurements. A DNA-DNA hybridization value of $92 \%$ was calculated.

The physiological characters of the novel species, determined using standard methods (On \& Holmes, 1991a, b, 1992; Ursing et al., 1994; On et al., 1996), along with those of all Campylobacter reference strains are represented in Table 1 and in the species description. These characteristics allowed differentiation of the rabbit isolates from recognized Campylobacter species (Table 1).

Morphological characteristics were determined using transmission electron microscopy (TEM). For TEM, 48h-old cells were negatively stained with $1 \%$ (w/v) phosphotungstic acid (Sigma) and examined using a Zeiss E900 TEM microscope. Cells were spiral shaped, with bipolar unsheathed flagella; periplasmic fibres on the surface were not observed (data not shown).

For the determination of $\mathrm{G}+\mathrm{C}$ content, DNA was enzymically degraded into nucleosides as described by Mesbah \& Whitman (1989). The nucleoside mixture was separated by HPLC using a Waters SymmetryShield C8
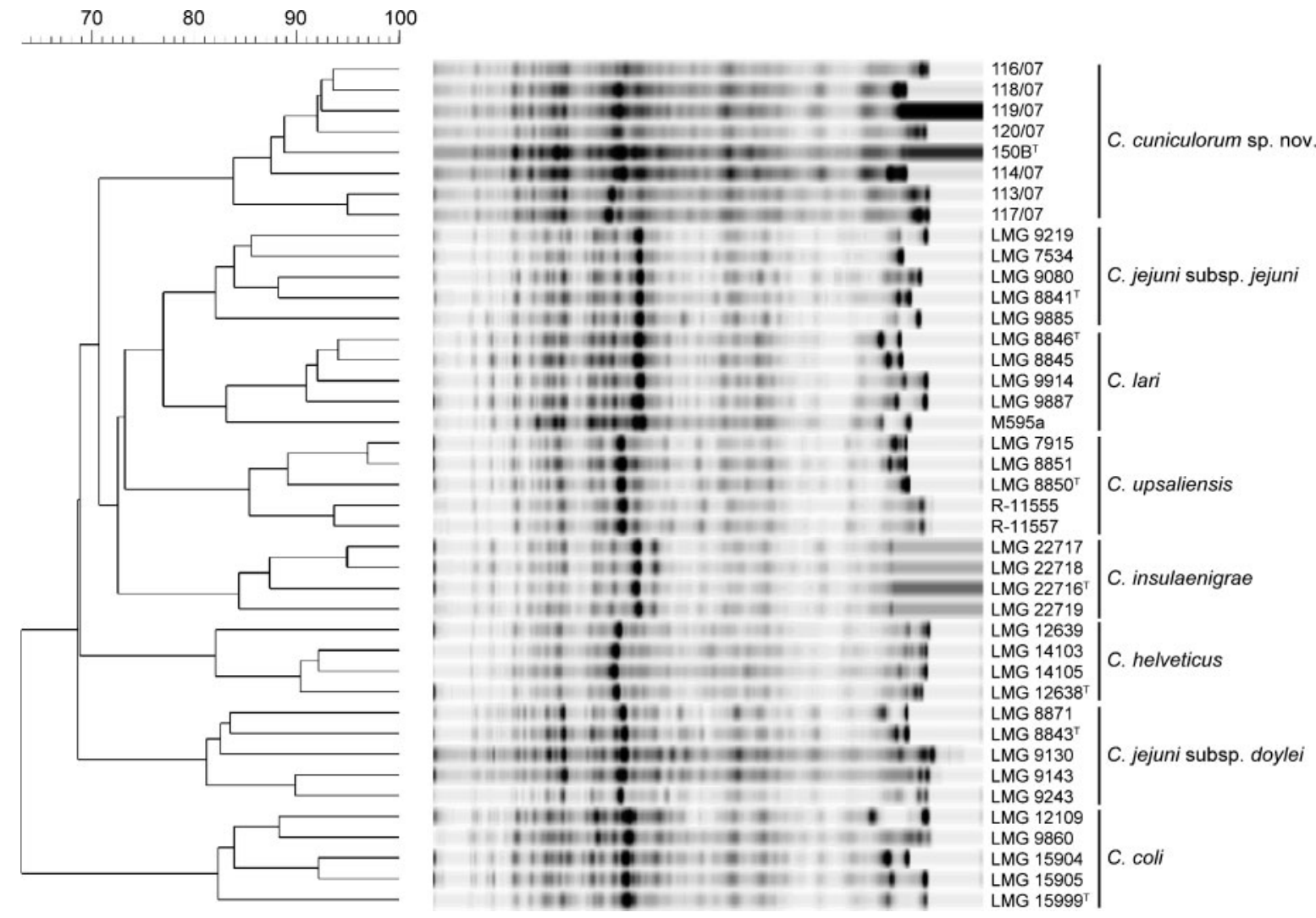

Fig. 2. Dendrogram of the eight strains of Campylobacter cuniculorum sp. nov. and representatives of other Campylobacter species based on UPGMA cluster analysis of one-dimensional SDS-PAGE cell protein profiles. 


\section{Table 1. Phenotypic characteristics of Campylobacter species}

Species/subspecies: 1, Campylobacter cuniculorum sp. nov.; 2, C. canadensis; 3, C. coli; 4, C. concisus; 5, C. curvus; 6, C. fetus subsp. fetus; 7, C. fetus subsp. venerealis; 8, C. gracilis; 9, C. helveticus; 10, C. hominis; 11, C. hyointestinalis subsp. hyointestinalis; 12, C. hyointestinalis subsp. lawsonii; 13, C. insulaenigrae; 14, C. jejuni subsp. doylei; 15, C. jejuni subsp. jejuni; 16, C. lanienae; 17, C. lari; 18, C. mucosalis; 19, C. rectus; 20, C. showae; 21, C. sputorum; 22, C. upsaliensis. Data for reference species were taken from On et al. (1996), Foster et al. (2004), Vandamme et al. (2005) and Inglis et al. (2007). No taxa grow aerobically at $37^{\circ} \mathrm{C} .+, 90-100 \%$ Strains positive; $(+), 75-89 \%$ positive; v, $26-74 \%$ positive; $(-), 11-25 \%$ positive;,$- 0-10 \%$ positive; ND, no data available. mCCDA, modified-charcoal cefoperazone deoxycholate agar; TSI agar, triple sugar-iron agar; TTC, triphenyl tetrazolium chloride.

\begin{tabular}{|c|c|c|c|c|c|c|c|c|c|c|c|c|c|c|c|c|c|c|c|c|c|c|}
\hline Characteristic & 1 & 2 & 3 & 4 & 5 & 6 & 7 & 8 & 9 & 10 & 11 & 12 & 13 & 14 & 15 & 16 & 17 & 18 & 19 & 20 & 21 & 22 \\
\hline$\alpha$-Haemolysis & + & - & $(-)$ & $(-)$ & $(-)$ & - & $\mathrm{V}$ & - & + & ND & $\mathrm{V}$ & $\mathrm{V}$ & ND & + & + & + & $\mathrm{V}$ & - & + & + & + & + \\
\hline Oxidase & + & + & + & $\mathrm{V}$ & + & + & + & - & + & + & + & + & + & + & + & + & + & + & + & $\mathrm{V}$ & + & + \\
\hline Catalase & + & $\mathrm{V}$ & + & - & - & + & $(+)$ & V & - & - & + & + & + & $\mathrm{V}$ & + & + & + & - & $(-)$ & + & $\mathrm{V}$ & - \\
\hline Alkaline phosphatase & - & - & - & $\mathrm{V}$ & $\mathrm{V}$ & - & - & - & - & - & - & $(-)$ & ND & - & - & + & - & $(+)$ & - & - & - & - \\
\hline$\gamma$-Glutamyltranspeptidase & - & $(+)$ & - & - & ND & - & $\mathrm{ND}$ & $\mathrm{ND}$ & - & $\mathrm{ND}$ & - & - & $\mathrm{ND}$ & - & - & $\mathrm{ND}$ & - & $\mathrm{ND}$ & $\mathrm{ND}$ & ND & - & - \\
\hline Urease & - & $\mathrm{V}$ & - & - & - & - & - & - & - & - & - & - & - & - & - & - & $\mathrm{V}$ & - & - & - & $\mathrm{V}^{*}$ & - \\
\hline \multicolumn{23}{|l|}{ Hydrolysis of: } \\
\hline Hippurate & - & - & - & - & $(-)$ & - & - & - & - & - & - & - & - & + & + & - & - & - & - & - & - & - \\
\hline Indoxyl acetate & + & - & + & - & V & - & - & $\mathrm{V}$ & + & - & - & - & - & + & + & - & - & - & + & - & - & + \\
\hline \multicolumn{23}{|l|}{ Reduction of: } \\
\hline Nitrate & + & $\mathrm{v}$ & + & $(-)$ & + & + & + & $(+)$ & + & - & + & + & + & - & + & + & + & - & + & + & + & + \\
\hline Selenite & - & ND & $\mathrm{V}$ & $(-)$ & - & $(+)$ & - & - & - & - & + & + & $\mathrm{ND}$ & - & + & + & + & - & + & + & + & + \\
\hline TTC & $\mathrm{V}$ & $\mathrm{ND}$ & + & - & $\mathrm{V}$ & - & - & - & - & ND & - & - & $\mathrm{ND}$ & $\mathrm{V}$ & + & $\mathrm{ND}$ & + & - & - & - & - & $\mathrm{V}$ \\
\hline Trace $\mathrm{H}_{2} \mathrm{~S}$ production on TSI agar & - & $\mathrm{V}$ & - & - & $(-)$ & - & - & - & - & - & + & + & - & - & - & - & - & + & - & $\mathrm{V}$ & + & - \\
\hline \multicolumn{23}{|l|}{ Growth at/in/on: } \\
\hline $25{ }^{\circ} \mathrm{C}$ (microaerobic) & - & - & - & - & - & + & + & - & - & - & - & - & - & - & - & - & - & - & - & - & - & - \\
\hline $37^{\circ} \mathrm{C}$ (microaerobic) & + & + & + & + & $\mathrm{V}$ & + & + & - & + & + & + & + & + & + & + & + & + & + & - & $\mathrm{V}$ & + & + \\
\hline $42{ }^{\circ} \mathrm{C}$ (microaerobic) & $(+)$ & + & + & $(+)$ & $\mathrm{V}$ & $(+)$ & - & $\mathrm{V}$ & + & $(-)$ & + & + & - & - & + & + & + & + & $(-)$ & V & + & + \\
\hline $37^{\circ} \mathrm{C}$ (anaerobic) & - & + & - & + & + & $(-)$ & $\mathrm{V}$ & + & - & + & - & + & - & - & - & + & - & + & + & + & + & - \\
\hline Nutrient agar & + & - & + & $(-)$ & + & + & + & + & $(+)$ & $\mathrm{ND}$ & + & + & $\mathrm{ND}$ & + & + & $\mathrm{ND}$ & + & + & $(-)$ & $\mathrm{V}$ & + & + \\
\hline $\mathrm{mCCDA}$ & $(+)$ & + & + & $(-)$ & $(+)$ & + & + & $\mathrm{V}$ & + & ND & + & + & ND & + & + & ND & + & + & - & + & $(+)$ & + \\
\hline MacConkey agar & - & + & $\mathrm{V}$ & - & $(+)$ & $(+)$ & $\mathrm{V}$ & $(+)$ & - & - & $\mathrm{V}$ & $\mathrm{V}$ & $\mathrm{ND}$ & - & - & + & - & $(+)$ & - & + & $\mathrm{V}$ & - \\
\hline $1 \%$ Glycine & - & $\mathrm{V}$ & + & $(-)$ & + & + & - & + & $\mathrm{V}$ & + & + & $\mathrm{V}$ & + & $(-)$ & + & - & + & $\mathrm{V}$ & + & $\mathrm{V}$ & + & + \\
\hline $2 \% \mathrm{NaCl}$ & - & ND & - & $(-)$ & $\mathrm{V}$ & - & - & $\mathrm{V}$ & - & + & - & - & - & - & - & - & $(+)$ & + & $\mathrm{V}$ & + & + & - \\
\hline $1 \%$ Bile & $\mathrm{V}$ & $\mathrm{ND}$ & $(+)$ & - & - & + & + & - & + & $\mathrm{ND}$ & + & $(+)$ & $\mathrm{ND}$ & + & + & $\mathrm{ND}$ & + & + & - & - & $\mathrm{V}$ & + \\
\hline Requirement for $\mathrm{H}_{2}$ & - & - & - & + & + & - & - & + & - & + & $\mathrm{v}$ & $\mathrm{V}$ & $\mathrm{ND}$ & - & - & - & - & + & + & + & - & - \\
\hline \multicolumn{23}{|l|}{ Resistance to: } \\
\hline Cephalotin & $(+)$ & - & + & - & - & - & - & - & - & - & $(-)$ & - & + & - & + & + & + & - & - & - & - & $(-)$ \\
\hline Nalidixic acid & $\mathrm{V}$ & $\mathrm{V}$ & - & $(+)$ & + & + & $\mathrm{V}$ & $\mathrm{V}$ & - & V & + & + & + & - & - & + & $\mathrm{V}$ & $(+)$ & $(+)$ & - & $(+)$ & - \\
\hline
\end{tabular}

${ }^{*}$ Strains of biovar paraureolyticus are urease-positive; other strains are urease-negative (On et al., 1998). 
column maintained at $37{ }^{\circ} \mathrm{C}$. The solvent was $0.02 \mathrm{M}$ $\left(\mathrm{NH}_{4}\right) \mathrm{H}_{2} \mathrm{PO}_{4} \quad(\mathrm{pH} 4.0)$ with $1.5 \%$ acetonitrile. Nonmethylated $\lambda$-phage DNA (Sigma) was used as the calibration reference. The DNA G $+\mathrm{C}$ content of strain $150 \mathrm{~B}^{\mathrm{T}}$ was $32.4 \mathrm{~mol} \%$. This value is within the range reported for the genus Campylobacter (29-47 mol\%) (Vandamme et al., 2005).

In conclusion, the results of this polyphasic taxonomic study indicate that the isolates recovered from the caecal contents of rabbits represent a homogeneous novel species within the genus Campylobacter, for which we propose the name Campylobacter cuniculorum sp. nov.

\section{Description of Campylobacter cuniculorum sp. nov.}

Campylobacter cuniculorum (cu.ni.cu.lo'rum. L. gen. pl. n. cuniculorum of rabbits).

Cells are spiral, Gram-negative rods, motile, $0.2-0.4 \mu \mathrm{m}$ wide and 1.9-3.3 $\mu \mathrm{m}$ long, possessing a single flagellum at both poles. After subculturing on nutrient sheep-blood agar, colonies are grey-green, flat with rough margins and slightly mucoid-looking; after $72-96 \mathrm{~h}$ at $37^{\circ} \mathrm{C}$ under microaerobic conditions, colonies are smooth, $\alpha$-haemolytic, $1-2 \mathrm{~mm}$ in diameter. Colony appearance on modified-charcoal cefoperazone deoxycholate agar (mCCDA) and cefoperazone, amphotericin B, teicoplanin selective supplement (CAT) is similar to that on nutrient agar but growth on the first medium is slightly restricted. Strictly microaerobic. Able to grow at $37^{\circ} \mathrm{C}$ and most strains grow at $42{ }^{\circ} \mathrm{C}$; no growth at $25{ }^{\circ} \mathrm{C}$ or under anaerobic or aerobic conditions. Hydrogen is not required for growth. Oxidase and catalase are produced, but not urease, $\gamma$-glutamyltranspeptidase or alkaline phosphatase. Hydrolyses indoxyl acetate but not hippurate, and reduces nitrate but not selenite. Some strains reduce triphenyl tetrazolium chloride (TTC) and grow on nutrient agar without blood but not on MacConkey agar. No growth occurs in the presence of $1 \%(\mathrm{w} / \mathrm{v})$ glycine and $2 \%(\mathrm{w} / \mathrm{v})$ $\mathrm{NaCl}$ and only few strains grow in the presence of $1 \%(\mathrm{w} /$ v) bile. Most strains are resistant to ( $\mu \mathrm{g}$ per disc) nalidixic acid (30) and cephalothin (30) by disc diffusion test. Strains have been recovered from rabbit caecal contents but pathogenicity is unknown. The $\mathrm{G}+\mathrm{C}$ content of the type strain is $32.4 \mathrm{~mol} \%$.

The type strain is $150 \mathrm{~B}^{\mathrm{T}}\left(=\mathrm{LMG} 24588^{\mathrm{T}}=\mathrm{CCUG} 56289^{\mathrm{T}}\right)$, which was isolated from a rabbit in 2005.

\section{Acknowledgements}

We thank Dr Maria Renzi (Istituto Zooprofilattico Sperimentale della Lombardia e dell'Emilia Romagna, Bologna) for access to samples of rabbit caecal contents. We would also like to thank Dr Jean Euzéby (École Nationale Vétérinaire, Toulouse, France) for help with naming the novel species, Professor Roberto Chiocchetti (Department of Veterinary Morphophysiology and Animal Productions, University of Bologna, Italy) for help with the TEM analysis and Professor Valeria Sanguinetti for all the support given.

\section{References}

Bolton, F. J., Wareing, D. R. A., Skirrow, M. B. \& Hutchinson, D. N. (1992). Identification and biotyping of campylobacters. In Identification Methods in Applied and Environmental Microbiology, pp. 151-161. Edited by R. G. Board, D. Jones \& F. A Skinner. Oxford: Blackwell Scientific.

Denis, M., Soumet, C., Rivoal, K., Ermel, G., Blivet, D., Salvat, G. \& Colin, P. (1999). Development of a m-PCR assay for simultaneous identification of Campylobacter jejuni and C. coli. Lett Appl Microbiol 29, 406-410.

Ezaki, T., Hashimoto, Y. \& Yabuuchi, E. (1989). Fluorometric deoxyribonucleic acid-deoxyribonucleic acid hybridization in microdilution wells as an alternative to membrane filter hybridization in which radioisotopes are used to determine genetic relatedness among bacterial strains. Int J Syst Bacteriol 39, 224-229.

Foster, G., Holmes, B., Steigerwalt, A. G., Lawson, P. A., Thorne, P., Byrer, D. E., Ross, H. M., Xerry, J., Thompson, P. M. \& Collins, M. D. (2004). Campylobacter insulaenigrae sp. nov., isolated from marine mammals. Int J Syst Evol Microbiol 54, 2369-2373.

Inglis, G. D., Hoar, B. M., Whiteside, D. P. \& Morck, D. W. (2007). Campylobacter canadensis sp. nov., from captive whooping cranes in Canada. Int J Syst Evol Microbiol 57, 2636-2644.

Jukes, T. H. \& Cantor, C. R. (1969). Evolution of protein molecules. In Mammalian Protein Metabolism, vol. 3, pp. 21-132. Edited by H. N. Munro. New York: Academic Press.

Kärenlampi, R. I., Tolvanen, T. P. \& Hänninen, M. L. (2004). Phylogenetic analysis and PCR-restriction fragment length polymorphism identification of Campylobacter species based on partial groEL gene sequences. J Clin Microbiol 42, 5731-5738.

Korczak, B. M., Stieber, R., Emler, S., Burnens, A. P., Frey, J. \& Kuhnert, P. (2006). Genetic relatedness within the genus Campylobacter inferred from rpoB sequences. Int J Syst Evol Microbiol 56, 937945.

Lawson, A. J., Linton, D., Stanley, J. \& Owen, R. J. (1997). Polymerase chain reaction detection and speciation of Campylobacter upsaliensis and $C$. helveticus in human faeces and comparison with culture techniques. J Appl Microbiol 83, 375-380.

Linton, D., Owen, R. J. \& Stanley, J. (1996). Rapid identification by PCR of the genus Campylobacter and of five Campylobacter species enteropathogenic for man and animals. Res Microbiol 147, 707-718.

Mesbah, M. \& Whitman, W. B. (1989). Measurement of deoxyguanosine/thymidine ratios in complex mixtures by high-performance liquid chromatography for determination of the mole percentage guanine + cytosine of DNA. J Chromatogr 479, 297-306.

On, S. L. \& Holmes, B. (1991a). Effect of inoculum size on the phenotypic characterization of Campylobacter species. J Clin Microbiol 29, 923-926.

On, S. L. \& Holmes, B. (1991b). Reproducibility of tolerance tests that are useful in the identification of campylobacteria. J Clin Microbiol 29, $1785-1788$.

On, S. L. \& Holmes, B. (1992). Assessment of enzyme detection tests useful in identification of campylobacteria. J Clin Microbiol 30, 746749.

On, S. L., Holmes, B. \& Sackin, M. J. (1996). A probability matrix for the identification of campylobacters, helicobacters and allied taxa. J Appl Bacteriol 81, 425-432.

On, S. L. W., Atabay, H. I., Correy, J. E. L., Harrington, C. S. \& Vandamme, P. (1998). Emended description of Campylobacter sputorum and revision of its infrasubspecific (biovar) divisions, including C. sputorum biovar paraureolyticus, a urease-producing variant from cattle and humans Int J Syst Bacteriol 48, 195-206. 
Pitcher, D. G., Saunders, N. A. \& Owen, R. J. (1989). Rapid extraction of bacterial genomic DNA with guanidium thiocyanate. Lett Appl Microbiol 8, 151-156.

Pot, B., Vandamme, P. \& Kersters, K. (1994). Analysis of electrophoretic whole-organism protein fingerprints. In Chemical Methods in Prokaryotic Systematics, pp. 493-521. Edited by M. Goodfellow \& A. G. O'Donnell. Chichester: Wiley.

Prescott, J. F. \& Bruin-Mosch, C. W. (1981). Carriage of Campylobacter jejuni in healthy and diarrheic animals. Am J Vet Res 42, 164-165.

Reynaud, A., Dromigny, E. \& Courdavault, D. (1993). Méthodes d'isolement et premiers éléments de caractérisation de bactéries Campylobacterlike chez le lapin sevré. Rev Med Vet (Toulouse) 144, 317-322 (in French).

Sebald, M. \& Véron, M. (1963). Teneur en bases de l'ADN et classification des vibrions. Ann Inst Pasteur (Paris) 105, 897-910 (in French).

Ursing, J. B., Lior, H. \& Owen, R. J. (1994). Proposal of minimal standards for describing new species of the family Campylobacteraceae. Int J Syst Bacteriol 44, 842-845.
Vandamme, P., Pot, B. \& Kersters, K. (1991). Differentiation of campylobacters and campylobacter-like organisms by numerical analysis of the one-dimensional electrophoretic protein patterns. Syst Appl Microbiol 14, 57-66.

Vandamme, P., Dewhirst, F. E., Paster, B. J. \& On, S. L. W. (2005). Genus I. Campylobacter Sebald and Véron 1963, 907 ${ }^{\mathrm{AL}}$. In Bergey's Manual of Systematic Bacteriology, vol. 2, part C, pp. 1147-1160. Edited by D. J. Brenner, N. R. Krieg, J. T. Staley \& G. M. Garrity. New York: Springer.

Weber, A., Lembke, C. \& Schäfer, R. (1982). Untersuchungen zum Vorkommen von Campylobacter jejuni bei Kaninchen, Meerschweinchen, Ratten und Mausen in der Versuchstierhaltung. Berl Munch Tierarztl Wochenschr 95, 488-489 (in German).

Zanoni, R. G., Rossi, M., Giacomucci, D., Sanguinetti, V. \& Manfreda, G. (2007). Occurrence and antibiotic susceptibility of Helicobacter pullorum from broiler chickens and commercial laying hens in Italy. Int J Food Microbiol 116, 168-173. 